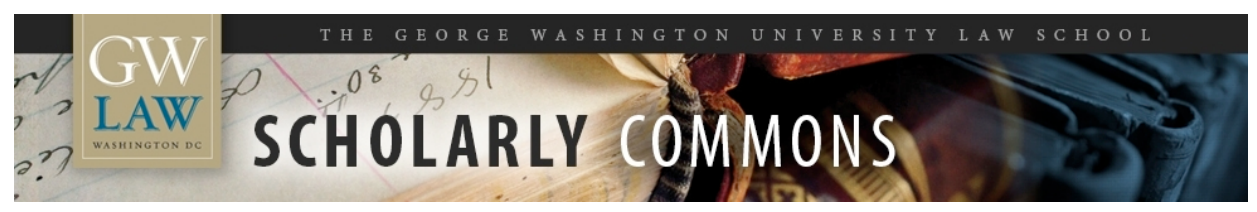

\title{
Making Black and Brown Lives Matter: Incorporating Race into the Criminal Procedure Curriculum
}

\author{
Cynthia Lee \\ George Washington University Law School, cylee@law.gwu.edu
}

Follow this and additional works at: https://scholarship.law.gwu.edu/faculty_publications

Part of the Law Commons

\section{Recommended Citation}

Lee, Cynthia, Making Black and Brown Lives Matter: Incorporating Race into the Criminal Procedure Curriculum (2016). 60 St. Louis U. L.J. 481 (2016); GWU Law School Public Law Research Paper No. 2017-57; GWU Legal Studies Research Paper No. 2017-57. Available at SSRN: http://ssrn.com/ abstract $=3011657$

This Article is brought to you for free and open access by the Faculty Scholarship at Scholarly Commons. It has been accepted for inclusion in GW Law Faculty Publications \& Other Works by an authorized administrator of Scholarly Commons. For more information, please contact spagel@law.gwu.edu. 


\title{
MAKING BLACK AND BROWN LIVES MATTER: INCORPORATING RACE INTO THE CRIMINAL PROCEDURE CURRICULUM
}

\author{
CYNTHIA LEE*
}

The fatal shooting of Michael Brown, an African American teenager, in August 2014 by a White police officer in Ferguson, Missouri, and the death of Eric Garner, an African American man who died after being put into a chokehold by a New York City police officer in July 2014, led to a firestorm of protests under the moniker of "Black Lives Matter." Many Blacks saw these two deaths and the failure to indict the officers involved as reflecting a lack of concern for Black lives. ${ }^{2}$

\footnotetext{
* Cynthia Lee is the Charles Kennedy Poe Research Professor of Law, The George Washington University Law School, and the author of MURDER AND THE REASONABLE MAN: PASSION AND FEAR IN THE CRIMINAL COURTROOM (N.Y. Univ. Press 2003) and CRIMINAL LAW: CASES AND MATERIALS (3d ed. West 2014) (written with Angela Harris). Many of the articles described in this Article will be included in her forthcoming Criminal Procedure casebook, CRIMINAL PROCEDURE: CASES AND MATERIALS (West 2016) (written with L. Song Richardson \& Tamara Lawson). Professor Lee thanks Charles Calleros, César Cuauhtémoc García Hernández, and L. Song Richardson for their helpful comments on a draft of this paper. She also thanks Matthew Halldorson and Mario Kolev from The George Washington University Law School for their research assistance, and Joseph Welling, Managing Editor of the Teaching Issue, and the students on the Saint Louis University Law Journal for their editorial assistance in the production of this Article.

1. Jonathan Capehart, From Trayvon Martin to 'Black Lives Matter', WASH. POST: POST PARTISAN (Feb. 27, 2015), http://www.washingtonpost.com/blogs/post-partisan/wp/2015/02/27/ from-trayvon-martin-to-black-lives-matter/ [http://perma.cc/3JRP-MEA2]; Claudia Rankine, 'The Condition of Black Life Is One of Mourning', N.Y. TMMES MAG. (June 22, 2015), http://www.ny times.com/2015/06/22/magazine/the-condition-of-black-life-is-one-of-mourning.html [http://per ma.cc/F3FA-ZT7P] (discussing origins of the Black Lives Matter movement).

2. Monica Davey \& Julie Bosman, Protests Flare After Ferguson Police Officer Is Not Indicted, N.Y. TIMES, Nov. 25, 2014, at A1, http://www.nytimes.com/2014/11/25/us/ferguson-dar ren-wilson-shooting-michael-brown-grand-jury.html [http://perma.cc/LX5Y-YX85] (describing the civil unrest in Ferguson as being based on a perceived "pattern of police brutality against young black men"); Adam Chandler, Eric Garner and Michael Brown: Deaths Without Indictments, ATLANTIC (Dec. 3, 2014), http://www.theatlantic.com/nationaV/archive/2014/12/ericgarner-grand-jury-no-indictment-nypd/383392/ [http://perma.cc/FZ59-J8SJ] (noting that New York Police Department Officer Daniel Pantaleo was not indicted by a New York grand jury for the death of Eric Garner); Jonathan Capehart, 'Black Lives Matter' to Everyone-Finally, WASH. POST: POSTPARTISAN (Dec. 5, 2014), http://www.washingtonpost.com/blogs/post-partisan/wp/20
} 
Blacks and Latinos constitute only thirty percent of the United States population but make up fifty-six percent of the inmates in prisons and jails across the country. ${ }^{3}$ The disproportionate numbers of Black and Brown people behind bars should be reason alone to pay attention to the role of race in our criminal justice system, but the United States Supreme Court and many lower courts continue to turn a blind eye to race and the possibility that racial biasexplicit or implicit-may contribute to the decisions that are made by police, prosecutors, and jurors to arrest, charge, and convict. ${ }^{4}$ Likewise, many criminal procedure casebooks present the Supreme Court's criminal procedure jurisprudence as a series of race-neutral decisions. If the law professor who teaches Criminal Procedure wants students to think about race, the professor often has to supplement the cases in the traditional casebook with other materials. ${ }^{5}$ This Article is aimed at helping the professor who wants to

14/12/05/black-lives-matter-to-everyone-finally/ [http://perma.cc/6NJ3-F99A] (noting that the failure to indict in both the Brown and Garner cases reflected a failure of "the accountability that our criminal justice system strives for"). In the Ferguson case, an investigation into the shooting by the United States Department of Justice found that the physical and forensic evidence supported Officer Wilson's claim of self-defense, and that the officer shot Brown as Brown was moving toward the officer. U.S. DEP'T OF JUSTICE, DEPARTMENT OF JUSTICE REPORT REGARDING THE CRIMINAL INVESTIGATION INTO THE SHOOTING DEATH OF MICHAEL BROWN BY FERguSON, MisSOURI POLICE OFFICER DARREN WILSON 6-8 (Mar. 4, 2015), http://www.jus tice.gov/sites/default/files/opa/pressreleases/attachments/2015/03/04/doj_report_on_shooting_of michael_brown_1.pdf [http://perma.cc/YV4Q-PKGK]. In the New York case, the City of New York agreed to pay \$5.9 million to the family of Eric Garner in a pretrial settlement of the civil lawsuit the family filed in the wake of Garner's death. Kevin Conlon \& Ray Sanchez, Eric Garner's Family Reacts to $\$ 5.9$ Million Settlement, CNN (July 14, 2015), http://www.cnn.com/ 2015/07/14/us/garner-nyc-settlement/ [http://perma.cc/9E CA-GGPT].

3. Nazgol Ghandnoosh, The Sentencing Project, Black lives Matter: ELIMINATING RACLAL INEQUITY IN THE CRIMINAL JUSTICE SYSTEM 3 (2015).

4. See, e.g., Devon W. Carbado, (E)racing the Fourth Amendment, 100 MICH. L. REV. 946, 977-78 (2002) (critiquing Justice O'Connor's colorblind approach in Florida v. Bostick); Anthony C. Thompson, Stopping the Usual Suspects: Race and the Fourth Amendment, 74 N.Y.U. L. REV. 956, 963-64 (1999) (critiquing the Supreme Court's colorblind opinion in Terry v. Ohio); Cynthia Lee, (E)Racing Trayvon Martin, 12 OhIo ST. J. CRIM. L. 91, 100-13 (2014) (critiquing the decision by the trial judge in the George Zimmerman murder trial to run a colorblind trial); see also Cynthia Lee, Making Race Salient: Trayvon Martin and Implicit Bias in a Not yet Post-Racial Society, 91 N.C. L. REV. 1555, 1556 (2013) (discussing the importance of making race salient if one is concemed about racial bias). Supreme Court Justice Sonia Sotomayor, the Supreme Court's first Latina justice, does pay attention to race. See, e.g., id. at 1611 (discussing comments by Justice Sotomayor, chastising a prosecutor for his reliance on racial stereotypes during his cross-examination of a witness).

5. Assigning supplemental material that focuses attention on racial issues can be risky for an untenured professor or a professor of color since students may resent having to read materials not in the casebook. Some students may think that the professor is pushing his or her own progressive agenda on them. If a professor is concerned about such issues, that professor may wish to adopt a casebook that already incorporates such materials. One criminal procedure 
incorporate race into the basic criminal procedure curriculum by providing references to specific supplemental materials that the professor can assign to her students.

One who wants to highlight race in the basic criminal procedure class has many opportunities to do so. One can start with Mapp v. Ohio, the case in which the Supreme Court applied the exclusionary rule to the states through the Due Process Clause. ${ }^{6}$ Few people know that Dollree Mapp, the woman behind this decision, was a strong-willed Black woman whose refusal to consent to the search of her home and her insistence that the police show her a warrant led to this historic decision. ${ }^{7}$ Ms. Mapp's refusal to cede her rights to the police led Professor Wayne LaFave to call her the "Rosa Parks of the Fourth Amendment." While the fact that Ms. Mapp was a Black woman probably had nothing to do with the Court's decision to apply the exclusionary rule to the states, it is noteworthy that a Black woman's refusal to let police search her house without a warrant (just like Rosa Parks' refusal to cede her seat at the front of the bus) was behind arguably one of the most important criminal procedure decisions the Supreme Court has ever issued.

Every criminal procedure professor I know teaches Katz v. United States, the seminal Supreme Court case on what constitutes a "search" within the meaning of the Fourth Amendment. ${ }^{9}$ In his concurring opinion, Justice Harlan announced a two-part test for deciding when a search has occurred. " 10 y understanding of the rule that has emerged from prior decisions is that there is a twofold requirement, first that a person have exhibited an actual (subjective) expectation of privacy and, second, that the expectation be one that society is prepared to recognize as "reasonable." "11 Even though it was announced in a concurring opinion, the Court has embraced Justice Harlan's reasonable expectation of privacy test as the test for a search. ${ }^{12}$

On its face, Katz seems like a case that has nothing to do with race or class. Not so, according to the late Professor William Stuntz who pointed out in his article, The Distribution of Fourth Amendment Privacy, that Katz's focus on

casebook that does this is CYNTHIA LEE, TAMARA LAWSON \& L. SONG RICHARDSON, CRIMINAL PRocedure: CASES AND MATERIALS (West 2016).

6. Mapp v. Ohio, 367 U.S. 643, 653, 660 (1961).

7. Ken Armstrong, Dollree Mapp, 1923-2014: "The Rosa Parks of the Fourth Amendment", MARSHALL PROJECT (Dec. 8, 2014), http://www.themarshallproject.org/2014/12/ 08/dollree-mapp-1923-2014-the-rosa-parks-of-the-fourth-amendment [http:/perma.cc/ZY9S-

A7J7].

8. Id.

9. Katz v. United States, 389 U.S. 347, 356-57 (1967).

10. Id. at 361 (Harlan, J., concurring).

11. Id.

12. E.g., Oliver v. United States, 466 U.S. 170, 177, 188 (1984); United States v. Jones, 132 S. Ct. 945, 950 (2012); Kyllo v. United States, 533 U.S. 27, 33 (2001). 
reasonable expectations of privacy benefits the wealthy and disadvantages poor people, particularly poor people of color living in the inner city. ${ }^{13}$ This is because most wealthy people live in single-family homes with a lot of space between them and their neighbors. ${ }^{14}$ This enables those with means to keep their lives and possessions fairly private. Conversely, poor people tend to live with many other people in multi-unit apartment dwellings or public housing units with thin walls, where everyone tends to know everyone else's business. $^{15}$

Whren $v$. United States ${ }^{16}$ offers a mother lode of opportunities to discuss race. In Whren, the Court held that the Fourth Amendment is not violated when police officers stop an individual who has committed a traffic violation, even if the real reason for the stop is merely a hunch that the individual is involved in criminal activity. ${ }^{17}$ The defendants, who were both Black, argued that if police officers are allowed to stop any motorist simply based on probable cause to believe the motorist has committed a traffic violation, "police officers might decide which motorists to stop based on decidedly impermissible factors, such as the race of the car's occupants. ${ }^{.18}$ In response to this concern, the Court said that any complaint about racial discrimination in being selected by police for a stop had to be vetted under the Equal Protection Clause, not the Fourth Amendment. ${ }^{19}$

Arguably, Whren gives police officers cover to engage in racial profiling or the targeting of individuals based on racial stereotypes linked to criminal activity. Since all the officer needs is probable cause to believe the individual in question has committed a traffic violation, the officer can pull over an individual even if the real reason the officer is doing so is because he thinks, based on the individual's race, that the individual is more likely to have drugs or contraband in the car. Many Blacks, including many prominent Blacks, have been subjected to racial profiling. ${ }^{20}$

13. William J. Stuntz, The Distribution of Fourth Amendment Privacy, 67 GEO. WASH. L. REV. 1265, 1272-73 (1999). Similarly, Christopher Slobogin notes that under Supreme Court case law, "the homes and belongings of poorer folk receive lesser constitutional protection from government searches." Christopher Slobogin, The Poverty Exception to the Fourth Amendment, 55 FLA. L. REV. 391, 403 (2003).

14. Stuntz, supra note 13, at 1270.

15. Id. at 1272 .

16. Whren v. United States, 517 U.S. 806 (1996).

17. Id. at 819.

18. Id. at 810 .

19. Id. at 813 .

20. For example, Cornel West, a prominent African American professor of philosophy at Princeton University, describes being shunned by numerous taxi drivers when he needed to catch a cab in New York City. CORNEL WEST, RACE MATTERS, at ix-x (1993). In his recently published book, Just Mercy, Bryan Stevenson, executive director of the Equal Justice Initiative, a professor at New York University Law School, and a well-known capital defense attorney, talks 
To help non-Black students understand the experience of being racially profiled, I like to assign Professor Paul Butler's short Legal Times article, 'Walking While Black': Encounters With the Police on My Street. ${ }^{21}$ In this article, Butler, a prominent criminal law professor at Georgetown Law School, describes the experience of being stopped by police officers who thought he was a burglary suspect when he was walking home from work one evening. ${ }^{22}$ The only thing Butler had in common with the men suspected of burglarizing the homes in the well-to-do neighborhood where Butler lived and was stopped was that he and they were young, Black, and male. Another article that does an excellent job of helping the reader feel what it is like to be racially profiled is Professor Devon Carbado's (E)racing the Fourth Amendment. ${ }^{23}$ In this article, Carbado, a law professor at the University of California at Los Angeles School of Law, describes two experiences in which he was racially profiled and treated like a criminal suspect, even though he was not guilty of any crime. ${ }^{24}$

When I teach Whren, I also like to assign Professor David Harris' "Driving While Black" and All Other Traffic Offenses, which does an excellent job of critiquing Whren. ${ }^{25}$ Harris argues that Whren will end up harming Black and Brown drivers because it gives police officers the green light to engage in racial profiling. ${ }^{26}$ As long as the officer can point to an observed traffic violation, the officer can pull over any driver, even if the real reason for the stop is a hunch. ${ }^{27}$ Harris points out that the most careful driver cannot avoid violating some traffic law during a short drive. ${ }^{28}$ When thus gives police the authority to pull over all drivers. The more significant problem, however, according to Harris, is that police will not pull over all drivers who are violating the law. Since they cannot pull over everyone, they will pull over just

about being questioned by a police officer who suspected Stevenson, who at the time was a young attorney parked outside his apartment listening to Sly and the Family Stone, was a would-be burglar. BRYAN STEVENSON, JUST MERCY: A STORY OF JUSTICE AND REDEMPTION 38-42 (2014). Patricia Williams, a well-respected law professor at Columbia Law School, tells the story of being turned away from a Benetton clothing store because the store clerk thought she was a would-be thief. PATRICIA J. WILLIAMS, THE ALCHEMY OF RACE AND RIGHTS 45-51 (1991).

21. Paul Butler, 'Walking While Black': Encounters With the Police on My Street, LEGAL TIMES, Nov. 10, 1997, at 23.

22. Id. at 23-24.

23. Carbado, supra note 4 , at 949.

24. Id. at $946,953,959-61$.

25. David A. Harris, "Driving While Black" and All Other Traffic Offenses: The Supreme Court and Pretextual Traffic Stops, 87 J. CRIM. L. \& CRIMINology 544, 545 (1997). I also like to show students a clip from Professor Harris' 1997 address on the Whren case before the Congressional Black Caucus. African Americans and Police Brutality, C-SPAN (Feb. 16, 2014), http://www.c-span.org/video/?c4484601/david-harris [http://perma.cc/3QXA-58FD].

26. Harris, supra note 25 , at $560,563$.

27. Id. at 558. Ordinarily, a hunch is not sufficient to detain an individual. Id. at $573 \mathrm{n} .183$.

28. Id. at 545 . 
those drivers they think are most likely to be involved in criminal activity, i.e. Black and Brown drivers. ${ }^{29}$ Harris then gives numerous examples of police doing just this. ${ }^{30}$

If one teaches United States v. Brignoni-Ponce, ${ }^{31}$ the 1975 case in which the Supreme Court held that Mexican appearance standing alone does not justify stopping all Mexican Americans to ask if they are aliens, ${ }^{32}$ one can expose the students to some critical race critiques of this decision. At first glance, Brignoni-Ponce seems like a good decision. This was the way I understood the case when I first read it. After all, the Court found that the stop in question violated the Fourth Amendment because Border Patrol agents relied exclusively on the apparent Mexican ancestry of the occupants in the vehicle to justify the stop. The Court, however, also stated in dictum, "The likelihood that any given person of Mexican ancestry is an alien is high enough to make Mexican appearance a relevant factor . . ...33

In La Migra in the Mirror: Immigration Enforcement and Racial Profiling on the Texas Border, Professor César Cuauhtémoc García Hernández argues that the Supreme Court in Brignoni-Ponce in essence endorsed racial profiling in the immigration context. ${ }^{34}$ Hernandez points out that it is quite easy for a law enforcement officer to find some reason other than apparent Mexican ancestry to justify stopping someone of apparent Mexican ancestry. ${ }^{35}$ The Brignoni-Ponce Court made this task even easier by spelling out reasons other than Mexican ancestry that can support a stop based on reasonable suspicion of illegal immigration activity. According to the Court, in deciding whether there is reasonable suspicion to stop a vehicle, officers may consider factors such as erratic driving, obvious attempts to evade officers, the fact that the vehicle appears to be heavily loaded, the fact that the vehicle contains an extraordinary number of passengers, and the fact that some passengers are trying to hide. ${ }^{36}$ Hernandez then recounts the time when he and his family were in Seattle, Washington, celebrating his brother's graduation from law school. He notes that under Brignoni-Ponce, his family could have easily been detained:

Rereading Justice Powell's words in Brignoni-Ponce . . I am reminded of how broad these factors reach. Recently, my family and I were in Seattle celebrating my brother's graduation from law school. Ten of us were crammed

29. Id. at 560 .

30. Id. at $560-69$.

31. United States v. Brignoni-Ponce, 422 U.S. 873 (1975).

32. Id. at 875 .

33. Id. at 887.

34. César Cuauhtémoc García Hernández, La Migra in the Mirror: Immigration Enforcement and Racial Profiling on the Texas Border, 23 NOTRE DAME J.L. ETHICS \& PUB. POL'Y 167, $183-84$ (2009).

35. Id. at 182.

36. Id. at $182-83$. 
into a seven-person van, including two of us who were crouched in the rear cargo compartment. Many of us were born in México and lived there at least a few years of our lives. A few of us currently live directly on the border. Our driver, my oldest brother, was unfamiliar with the Seattle neighborhood in which we were traveling. After the graduation ceremony, on our way back to the large house that we rented for the weekend, he got lost and circled an industrial waterfront neighborhood full of warehouses and cargo ports. I can only imagine how erratic and heavily loaded our oversized vehicle looked, and how "Mexican" its passengers appeared. I can only be grateful that we were not near "the border and its functional equivalents" where immigration officers have the Supreme Court's seal of constitutional approval to stop and question families like mine-too large, too Mexican, too lost-who are riding in a suspicious vehicle, an enormous blue van with sliding doors, fold-down seats, spare tires, and out-of-state license plates- to blend into the landscape. ${ }^{37}$

Another critique of Brignoni-Ponce that can be shared with students is University of California at Davis School of Law Dean Kevin Johnson's The Case Against Racial Profiling in Immigration Enforcement. ${ }^{38}$ In this article, Johnson focuses our attention on the following passage in Brignoni-Ponce: "The likelihood that any given person of Mexican ancestry is an alien is high enough to make Mexican appearance a relevant factor . . ." to justify a stop to ask if the person is an alien. Johnson asks us to consider how we would feel if the Supreme Court had instead said: " "[T] he likelihood that any given person of [African American] ancestry is [a criminal] is high enough to make [African American] appearance a relevant factor' in a criminal stop." most of us would be outraged at such a statement, yet the Supreme Court's similar statement in Brignoni-Ponce, regarding Mexican American appearance, largely went unnoticed. ${ }^{41}$

Johnson notes that in deciding that Mexican appearance was a relevant factor because of the high likelihood that any person of Mexican ancestry is an alien, i.e. an immigrant, the Supreme Court likely relied on the Government's assertion that eighty-five percent of the undocumented population in this country was of Mexican ancestry. ${ }^{42}$ Johnson points out that this figure is not an accurate figure since Mexican nationals actually constitute roughly half of the undocumented population, not eighty-five percent of that population. ${ }^{43}$ More

37. Id. at $184-85$.

38. Kevin R. Johnson, The Case Against Racial Profiling in Immigration Enforcement, 78 WASH. U. L.Q. 675, 694 (2000).

39. United States v. Brignoni-Ponce, 422 U.S. 873, 886-87 (1975).

40. Johnson, supra note 38, at 694.

41. Id.

42. Id. at 707 .

43. Id. at 708. In 2000, the Ninth Circuit held that "Hispanic appearance is, in general, of such little probative value that it may not be considered as a relevant factor" for courts to consider when deciding whether the officers had reasonable suspicion to stop an individual. United States 
importantly, Johnson argues that the Supreme Court should have focused on the percentage of Hispanic persons in the United States with lawful immigration statuses because these are the people harmed by racial profiling in immigration enforcement. ${ }^{44}$ Johnson points out that the vast majorityapproximately ninety percent-of Hispanics living in the United States are lawful permanent residents or United States citizens. ${ }^{45}$ Finally, Johnson argues that allowing Border Patrol agents to rely on "apparent Mexican ancestry" is problematic because it "reinforces negative, ill-conceived stereotypes" about persons of Mexican ancestry. ${ }^{46}$ Johnson notes that many of Mexican ancestry are actually "blond, blue-eyed and white," and some even "have red hair and hazel eyes." "Th Thus, "[t]he stereotype of the dark-haired, brown skinned (often linked to 'dirty') 'Mexican' ignores the rich diversity of physical appearances among Latinos." 48

Racial profiling affects more than just Black and Brown drivers. ${ }^{49}$ In Profiling Terror, Professor Sharon Davies notes that after the 9/11 attacks on the World Trade Center and the Pentagon, a new type of profiling emerged: the ethnic profiling of those perceived to be Arab or Muslim. ${ }^{50}$ Davies notes that in contrast to the widespread public condemnation of racial profiling of Blacks and Latinos at the time, many Americans endorsed the profiling of Muslims and Arabs. ${ }^{51}$ Davies argues that such profiling is misguided. ${ }^{52}$

v. Montero-Camargo, 208 F.3d 1122, 1135 (9th Cir. 2000). The court explained that the Hispanic population has grown so much since Brignoni-Ponce was decided that the mere fact that one looks Hispanic is of little or no use in deciding which Hispanics are undocumented. Id. at 1134. The court explained, "Brignoni-Ponce was handed down in 1975, some twenty-five years ago. Current demographic data demonstrate that the statistical premises on which its dictum relies are no longer applicable. The Hispanic population of this nation, and of the Southwest and Far West in particular, has grown enormously-at least five-fold in the four states referred to in the Supreme Court's decision." Id. at 1133. The court further explained that "[r]easonable suspicion requires particularized suspicion, and in an area in which a large number of people share a specific characteristic, that characteristic casts too wide a net to play any part in a particularized reasonable suspicion determination." Id. at 1134 (emphasis in original).

44. Johnson, supra note 38 , at 708.

45. Id. at 709 .

46. Id. at 710,714 .

47. Id. at 714-15 (emphasis in original).

48. Id. at 715 (internal citation omitted).

49. In his excellent book on race and class in the American criminal justice system, No Equal Justice, David Cole provides a list of characteristics that federal agents have asserted are a part of the "dirug courier profile." DAVID COLE, NO EQUAL JUSTICE: RACE AND CLASS IN THE AMERICAN CRIMINAL JUSTICE SYSTEM 47-49 (1999). Many of these characteristics, such as "arrived late at night" and "arrived early in the morning" and "one of first to deplane" and "one of last to deplane," contradict one another. Id. at 48.

50. Sharon L. Davies, Profiling Terror, 1 OHIO ST. J. CRIM. L. 45, 48 (2003).

51. Id. at 46 n.6.

52. Id. at 85 . 
Another type of profiling that occurs is the profiling of transgender individuals as sex workers. The term "walking while trans" has been coined to reflect the fact that police often assume trans people on the street are prostitutes. ${ }^{53}$ Pooja Gehi, executive director of the National Lawyers Guild, discusses this type of profiling in Gendered (In)security: Migration and Criminalization in the Security State and points out that poor transgender people of color are often profiled in this way. ${ }^{54}$

The automobile exception seems like a subject devoid of racial implications, but Professor David Sklansky shows how Wyoming $v$. Houghton, ${ }^{55}$ one of the main cases on the automobile exception, actually reinforces racial and class bias. In The Fourth Amendment and Common Law, Sklansky critiques the Supreme Court's increasing focus on whether the search in question constituted a search at early common law, as exemplified in Justice Scalia's opinion in Wyoming $v$. Houghton. ${ }^{56}$ Sklansky notes that this originalist focus-Sklansky calls it Scalia's new Fourth Amendment originalism ${ }^{57}$ makes it difficult to address inequities of race and class since eighteenthcentury rules of search and seizure codified class privilege, and did not reflect a commitment to equality. ${ }^{58}$

Terry v. Ohio ${ }^{59}$ provides fertile ground for discussing race. A professor can expose the students to many critiques of this decision. In Stopping the Usual Suspects: Race and the Fourth Amendment, Professor Anthony Thompson points out that nowhere in the Supreme Court's thirty-nine-page opinion does the Court mention that Terry and one of his companions were Black, the other companion was White, and Officer McFadden was White. ${ }^{60}$ In the excerpt that follows, Thompson then explains why this omission matters:

The Court stripped away the racial dimension of the case by removing all references to the participants' race. Although one cannot, of course, reconstruct the reasons for this rhetorical choice, it seems evident at least that this was a conscious choice. In his suppression hearing testimony, Detective

53. Joey L. MOgUL, ANDREA J. RITCHIE \& KAY WHTLLCK, QUEER (IN)JUSTICE: THE CRIMINALization of LGBT PEOPLE IN THE UNITED STATES 61 (2012) (noting that police profiling of transgender women of color as sex workers is so pervasive that queer communities have coined the phrase "walking while trans" to describe the experience of being targeted because of their gender and racial identities).

54. Pooja Gehi, Gendered (In) security: Migration and Criminalization in the Security State, 35 HARV. J.L. \& GENDER 357, 368-69 (2012).

55. Wyoming v. Houghton, 526 U.S. 295, 303-04 n.1, 309 (1999).

56. David A. Sklansky, The Fourth Amendment and Common Law, 100 COLUM. L. REV. 1739,1760 (2000).

57. Id.

58. Id. at $1772-73$.

59. Terry v. Ohio, 392 U.S. 1 (1968).

60. Anthony C. Thompson, Stopping the Usual Suspects: Race and the Fourth Amendment, 74 N.Y.U. L. REV. 956, 964 (1999). 
McFadden repeatedly referred to the "third man" (Katz) as a "white man"; the lawyers who questioned McFadden did so as well. Yet, the Court's opinion refers to him only as "the third man" or by name.

The removal of race from the case presented the Court with a dilemma, however. To determine whether to uphold McFadden's actions under the new "stop and frisk" doctrine, the Court had to ascertain precisely why McFadden stopped and frisked Terry. After all, an essential element of pre-Terry "probable cause". doctrine - and one the Court carried forward to the new "stop and frisk" rule-was that a search and seizure had to be supported by specific facts that could be weighed by an objective magistrate. But, with race eliminated from the case, the most obvious explanation for McFadden's suspicions and his subsequent actions was unavailable. The Court was left with McFadden's testimony that "he was unable to say precisely what first drew his eye to them."

What the Court did to "make sense" of McFadden's actions is best understood in the terms of narrative theory. As others have explained, a sound judicial opinion requires coherent factual and legal narratives. Such narratives permit the judges to clarify the events in their own minds and to present the facts and law in a manner that the legal community will generally accept. In Terry, the narrative upon which the Court settled was one of the "police officer as expert." 61

In Terry v. Ohio at Thirty-Five: A Revisionist View, Professor Lewis Katz explains how Terry and its progeny permit police to use the fact that the stop took place in a high crime neighborhood as a factor in the reasonable suspicion calculus. ${ }^{62}$ Katz argues that this allows a "high crime area" to serve as a proxy for race. ${ }^{63}$ Another law review article that can be assigned along with Terry $v$. Ohio is Professor L. Song Richardson's Arrest Efficiency and the Fourth Amendment. ${ }^{64}$ In this article, Richardson explains how implicit bias works, and how it can encourage police to stop and frisk Black individuals more often than White individuals. ${ }^{65}$

When covering Terry stops and frisks, one can also discuss the fairly recent lawsuit challenging the New York Police Department's stop and frisk policy. In 2008, ${ }^{66}$ a group of Blacks and Latinos filed a class action lawsuit against the City of New York ("City"), alleging that the New York Police

61. Id. at 967-69 (internal footnotes omitted).

62. Lewis R. Katz, Terry v. Ohio at Thirty-Five: A Revisionist View, 74 MISs. L.J. 423, 493 (2004).

63. Id.

64. L. Song Richardson, Arrest Efficiency and the Fourth Amendment, 95 MINN. L. REV. 2035, 2056 (2011).

65. Id. at 2038-39.

66. Second Amended Class Action Complaint at 1, Floyd v. City of New York, 959 F. Supp. 2d 540 (S.D.N.Y. 2013) (No. 08 Civ. 1034). 
Department's stop and frisk policy violated their rights under the Fourth Amendment and the Equal Protection Clause of the Fourteenth Amendment. ${ }^{67}$ Plaintiffs presented findings from an empirical study by Columbia Law Professor Jeffrey Fagan, showing that between January 2004 and June 2012, the New York City Police Department ("NYPD") conducted more than 4.4 million Terry stops. ${ }^{68}$ Over $80 \%$ of these 4.4 million stops were of Blacks or Hispanics. ${ }^{69}$ Despite this massive effort, weapons were seized in only $1.06 \%$ of the stops of Black individuals and $1.25 \%$ of stops of Hispanic individuals; contraband was seized in only $1.79 \%$ of the stops of Black individuals and $1.73 \%$ of the stops of Hispanic individuals. ${ }^{70}$ After a bench trial, United States District Court Judge Shira A. Scheindlin found that the City, through its police department, had adopted a policy of indirect racial profiling, targeting young Black and Latino men for stops based on local crime suspect data. ${ }^{71}$ In a 198page opinion, Judge Scheindlin held that the NYPD's stop and frisk policy resulted in the disproportionate and discriminatory stopping of Blacks and Hispanics in violation of the Equal Protection Clause and the Fourth Amendment. ${ }^{72}$ According to Judge Scheindlin, the NYPD's policy violated the Equal Protection Clause because it subjected all members of a racially defined group to heightened police enforcement simply because some members of that group are criminals, ${ }^{73}$ and it violated the Fourth Amendment rights of the plaintiffs because the stops lacked individualized reasonable suspicion. ${ }^{74}$

67. Floyd, 959 F. Supp. 2d at 556; Joseph Goldstein, Trial to Start in Class-Action Suit on Constitutionality of Stop-and-Frisk Tactic, N.Y. TIMES, Mar. 18, 2013, at A15, http://www.ny times.com/2013/03/18/nyregion/stop-and-frisk-trial-to-open-this-week-in-federal-court.html [http://perma.cc/4RPE-GRL4].

68. Second Supplemental Report of Jeffrey Fagan, Ph.D. at 10 tbl.1, Floyd, 959 F. Supp. 2d 540 (No. 08 Civ. 1034) [hereinafter Fagan Report]; Floyd, 959 F. Supp. 2d at 558.

69. Floyd, 959 F. Supp. 2d at 559. Even though Blacks constituted $23 \%$ and Latinos constituted $29 \%$ of New York City's population at the time, $52 \%$ of the 4.4 million individuals stopped by NYPD officers were Black and 31\% were Latinos. Id. Whites, who made up 33\% of New York City's population, constituted only $10 \%$ of the individuals stopped. Id.

70. Fagan Report, supra note 68, at 35 tbl.15.

71. Floyd, 959 F. Supp. 2d at 553, 562.

72. Id. at 562 .

73. Id. at 563 .

74. Id. at 660 . The City appealed Judge Scheindlin's ruling. On October 31, 2013, the Second Circuit Court of Appeals stayed Judge Scheindlin's ruling, suggesting that she misapplied a local rule regarding transfer of related cases and violated ethics rules by giving media interviews responding to criticism of the District Court. Ligon v. City of New York, 538 F. App'x 101, 102 (2d Cir. 2013). The Second Circuit, however, did not rule on the merits of the appeal. Id. at 103. In February 2014, the Second Circuit lifted the stay and remanded the case back to the District Court so that the parties could engage in settlement discussions. Ligon v. City of New York, 743 F.3d 362, 365 (2d Cir. 2014). In March 2014, the City and the plaintiffs reached an agreement on a settlement whereby the City, under then newly-elected Mayor Bill de Blasio, would enact reforms, including "training, supervision, monitoring and discipline regarding stop- 
Illinois v. Wardlow, the case in which the Supreme Court held that flight in conjunction with a high crime neighborhood gives officers reasonable suspicion to stop and frisk individuals, provides another opportunity to discuss race. Underlying this decision is an assumption that flight from police suggests guilt. In "Black and Blue Encounters"-Some Preliminary Thoughts About Fourth Amendment Seizures: Should Race Matter?, Professor Tracey Maclin critiques Justice Scalia's suggestion in California $v$. Hodari $D .^{75}$ that flight from police supports any inference of guilt. ${ }^{76}$ Maclin explains:

[In California v. Hodari D.], Justice Scalia intimated that it is reasonable to detain young men who "scatter in panic upon the mere sighting of the police." For Scalia ... proverbial common sense [indicates that] "The wicked flee when no man pursueth."

From a police perspective, Justice Scalia's remarks may make sense . . . . Of course, this viewpoint, never considers that Hodari, a black youth, may have had alternative reasons for wanting to avoid the cops. Many persons who have never committed a crime have ambivalent or negative attitudes about the police. Perhaps, a youth like Hodari flees at the sight of police because he does not wish to drop his pants, as many black youths in Boston have been forced to do, just because cops suspect he belongs to a gang or is selling drugs.

Or maybe Hodari has had an older sibling or friend roughed up by the police, and does not wish to undergo a similar experience with the approaching officers. Perhaps Hodari has seen the video-tape of the Los Angeles police beating and kicking Rodney King, or he has seen the NBC video of Don Jackson, a former police officer himself, being pushed through a store window by Long Beach, California police officers for no reason. Maybe Hodari believed that the officer who wants to ask him "What's going on here?" may engage in similar brutality in his case. As California Assemblyman Curtis Tucker was quoted as saying: "When black people in Los Angeles see a police car approaching, 'They don't know whether justice will be meted out or whether judge, jury and executioner is pulling up behind them.,",77

Similarly, in Fleeing While Black, Amy Ronner argues there was not enough information to warrant the Wardlow Court's conclusion that Wardlow's flight from police in the neighborhood he was in gave police reasonable suspicion to stop him. ${ }^{78}$ Finally, in Transparent Adjudication and Social Science Research

and-frisk" policies. Floyd v. City of New York, 302 F.R.D. 69, 108 (S.D.N.Y. 2014). In return, the City dismissed its appeal on the constitutionality of stop and frisk. Floyd v. City of New York, 770 F.3d 1051, 1063 (2d Cir. 2014).

75. California v. Hodari D., 499 U.S. 621 (1991).

76. Tracey Maclin, "Black and Blue Encounters"-Some Preliminary Thoughts About Fourth Amendment Seizures: Should Race Matter?, 26 VAL. U. L. REV. 243, 276 (1991).

77. Id. (internal footnotes omitted).

78. Amy D. Ronner, Fleeing While Black: The Fourth Amendment Apartheid, 32 CoLUM. HuM. RTS. L. REV. 383, 385, 414 (2001). 
in Constitutional Criminal Procedure, Professors Tracey Meares and Bernard Harcourt share the results of a study of street stops in New York City released about three weeks before the Wardlow decision that found that for every twenty-six stops undertaken because the suspect fled the scene, only one stop resulted in an arrest. ${ }^{79}$ Meares and Harcourt conclude that " $[t]$ his astoundingly high [inverse] relationship between stops and arrests is suggestive that in highcrime urban communities where the population is disproportionately minority, flight from an identifiable police officer is a very poor indicator that crime is afoot." $" 80$

Florida v. Bostick ${ }^{81}$ is another case that is often included in criminal procedure casebooks to help students understand what constitutes a "seizure" of the person for purposes of the Fourth Amendment. Under the traditional test for a "seizure" of the person, a person is seized if the reasonable person in her shoes would not have felt free to leave. ${ }^{82}$ Florida $v$. Bostick established a modified test for a "seizure" of the person in cases in which factors not caused by law enforcement make it such that the reasonable person would not feel free to leave, such as the fact that the bus one is on might depart with all of one's possessions if one were to leave. ${ }^{83}$ In such cases, a person is "seized" within the meaning of the Fourth Amendment if the reasonable person in her shoes would not have felt free to decline the officer's requests or terminate the encounter with the police. ${ }^{84}$

When teaching Bostick, a criminal procedure professor can assign an excerpt from Professor Devon Carbado's (E) racing the Fourth Amendment. ${ }^{85}$ In this article, Carbado provides a critical race critique of Florida v. Bostick. Carbado explains how Justice O'Connor's colorblind opinion in Florida $v$. Bostick ignored the racial reality of a Black man being confronted by a White police officer, making it easy to conclude that Bostick-who in all likelihood did not feel free to leave or terminate the encounter with the officer-was not "seized" for Fourth Amendment purposes. ${ }^{86}$

79. Tracey L. Meares \& Bernard E. Harcourt, Foreword: Transparent Adjudication and Social Science Research in Constitutional Criminal Procedure, 90 J. CRIM L. \& CRIMTNOLOGY 733,790 (2000).

80. Id. at 792 .

81. Florida v. Bostick, 501 U.S. 429 (1991).

82. United States v. Mendenhall, 446 U.S. 544, 554 (1980).

83. Bostick, 501 U.S. at 435-36.

84. Id. at 437.

85. Carbado, supra note 4.

86. Id. at 976. To see how Carbado's critique is relevant even today, see Lee, (E)Racing Trayvon Martin, supra note 4 (using Carbado's critique of Justice O'Connor's colorblind opinion in Florida $v$. Bostick as a springboard for critiquing the colorblind handling of the trial of George Zimmerman, the neighborhood watch captain charged with murdering Trayvon Martin). If one teaches INS v. Delgado, 466 U.S. 210 (1984), one can assign a different part of Carbado's article where Carbado critiques INS v. Delgado. Carbado, supra note 4, at 990-99. 
In introducing the subject of police interrogations to the students, a professor might encourage students to think about how racial stereotypes and implicit bias might influence the interaction between the police officer and the suspect. In Wrongly Accused: Is Race a Factor in Convicting the Innocent?, the late Professor Andrew Taslitz relies on social science to explain why a police officer may think a Black suspect is lying when it is possible that the individual is simply being defensive and hostile. ${ }^{87}$

If one teaches the $E d w a r d s$ rule ${ }^{88}$ - the rule that once a suspect in custody asks for an attorney, all questioning must cease until an attorney is presentone knows that under Davis $v$. United States ${ }^{89}$ the suspect must clearly and unambiguously request an attorney in order to trigger the Edwards rule. ${ }^{90}$ To get students to think critically about Davis' clear request rule, the professor can assign an excerpt from Professor Janet Ainsworth's In a Different Register: The Pragmatics of Powerlessness in Police Interrogation. ${ }^{91}$ In this article, Ainsworth shows how legal rules requiring the use of direct language can adversely affect women and some ethnic minorities who "habitually adopt a speech register including indirect and qualified modes of expression very much like those observed in typical female language use. ${ }^{.92}$

\section{CONCLUSION}

This Article provides just a sampling of materials that can be used to incorporate the subject of race into the basic criminal procedure curriculum. Many other resources exist from which one can draw to incorporate not only race but also gender, class, sexual orientation, and gender identity into the curriculum.

If one is wondering why one should incorporate issues of race into the law school classroom, there are several good reasons to do so. Professor Cheryl Wade, who teaches Corporations, suggests "it is important to discuss race whenever relevant because [our] students will practice law in a society in which racism is ubiquitous but not always apparent and recognizable." $" 93$ Wade

87. Andrew E. Taslitz, Wrongly Accused: Is Race a Factor in Convicting the Innocent?, 4 OHIO ST. J. CRIM. L. 121, 125 (2006).

88. Edwards v. Arizona, 451 U.S. 477, 482, 485 (1981).

89. Davis v. United States, 512 U.S. 452 (1994).

90. Id. at 459.

91. Janet E. Ainsworth, In a Different Register: The Pragmatics of Powerlessness in Police Interrogation, 103 YALE L.J. 259 (1993).

92. Id. at 263.

93. Cheryl L. Wade, Attempting to Discuss Race in Business and Corporate Law Courses and Seminars, 77 ST. JOHN's L. REV. 901,904 (2003). Similarly, Professor Okianer Christian Dark notes that discussing issues of race, gender, class, sexual orientation, and disability in law school can better prepare students for the more diverse and multicultural society facing us all in the twenty-first century. Okianer Christian Dark, Incorporating Issues of Race, Gender, Class, 
goes on to note that "[i]gnoring issues of race in the law school's core courses and relegating such issues to Law and Race and Critical Race Theory seminars" marginalizes discussions of race. ${ }^{94}$ The result is that "[o]nly the students who enroll in 'race courses' have available opportunities to discuss race and racism." A5 Additionally, as Dean Kevin Johnson of the University of California at Davis School of Law suggests, "[i]ntegrating race into class discussion broadens the students' focus beyond the doctrine outlined in the case at hand (without diminishing its importance)," and raises students" awareness of how seemingly race-neutral law implicates social justice concerns. ${ }^{96}$ Professor Charles Calleros observes that incorporating issues of race into the classroom is an excellent vehicle for developing critical thinking skills because students usually care deeply about such issues and can challenge one another to analyze the issues from a variety of perspectives. ${ }^{97}$

Some might be opposed to efforts to incorporate race into the law school curriculum on the ground that doing so sends a message that White lives do not matter or that they do not matter as much as Black and Brown lives. Such concerns are similar to those that have animated the debate over the Black Lives Matter movement. In the past several weeks, "Black Lives Matter" signs in Bethesda, Maryland, and Washington, D.C., have been vandalized, blocking or cutting out the word "Black" from these signs. ${ }^{98}$ The hashtag "\#AllLives Matter" has become a popular response to the Black Lives Matter movement. ${ }^{99}$ Aware of popular sentiment against the Black Lives Matter movement, some presidential candidates have edited their campaign speeches, deleting the word "Black" from the "Lives Matter" slogan. 100

Sexual Orientation, and Disability Into Law School Teaching, 32 WILLAMETTE L. REV. 541, 553 (1996).

94. Wade, supra note 93 , at 904-05.

95. Id. at 905 .

96. Kevin R. Johnson, Integrating Racial Justice Into the Civil Procedure Survey Course, 54 J. Legal EdUC. 242, 243 (2004). Similarly, in Learning Law Through the Lens of Race, Professor Kim Forde-Mazrui argues that "law can be more adequately understood and evaluated when examined through the lens of race." Kim Forde-Mazrui, Learning Law Through the Lens of Race, 21 J. L. \& PoL. 1, 4 (2005). Forde-Mazrui explains that certain laws that are justified today in race-neutral terms may have developed with racially discriminatory purposes. $I d$. at 6 . If such laws are studied without critical examination through the lens of race, their racial history and that history's present day effects may be obscured. Id.

97. Charles R. Calleros, Training a Diverse Student Body for a Multicultural Society, 8 LA RAZA L.J. 140, 140 (1995).

98. Petula Dvorak, The 'Black' Adds Meaning to 'Lives Matter', WASH. POST, Aug. 7, 2015, at BI, http://www.washingtonpost.com/local/the-ugly-message-behind-erasing-black-from-blacklives-matter-signs/2015/08/06/1d87a892-3c57-1 le5-9c2d-ed991d848c48_story.html [http://per ma.cc/8GD2-FG4U].

99. Id.

100. Id. 
Petula Dvorak, a columnist for the Washington Post, explains why the "All Lives Matter" or "Lives Matter" labels are problematic:

It's like defacing "Support Our Troops" stickers to read "Support Our People" and wondering why military families would be offended.

Of course, we want to support all people, and, of course, all lives matter. But deliberately cutting out "Troops" or "Black" announces that the struggles and challenges of those populations are not distinct from those of everyone else. ${ }^{101}$

Dvorak continues:

Every day, much of America declares - in ways overt and subtle-that only some lives matter.

A job applicant named John gets a callback. Jamal doesn't.

A sidewalk in a predominantly white neighborhood gets meticulously maintained. The sidewalk in the mostly black neighborhood in the same city is crumbling.

[The \#BlackLivesMatter movement] is not arguing that Gay Lives don't matter, or Hispanic Lives don't matter or All Other Lives don't matter.

It is a reminder that a boy armed with nothing more than Skittles and a soda should not be shot dead because of that deep, insidious racism that America wants to pretend doesn't exist.

So when someone went to the River Road Unitarian Universalist Congregation in Bethesda last week and knifed the word "Black" out of the vinyl sign the church had hung on its lawn, it was a hostile act denying all the hard work we Americans still have ahead of us. ${ }^{102}$

If one makes a conscious effort to incorporate race into the criminal procedure curriculum, this does not mean that one thinks White lives do not matter. One is merely recognizing the significant role that race plays in our criminal justice system. One is recognizing that Black and Brown lives matter just as much as other lives. 